(RESEARCH ARTICLE)

\title{
Prevalence of E. coli serovars in broiler farms: Biosecurity and the disinfectants sensitivity in Egypt
}

Kaoud H A*, Iraqi Kassem M, M.M. Khalil and Ismail Eman Mohamed

Department of Veterinary Hygiene and Environmental Pollution, Faculty of Veterinary Medicine, Cairo University, GizaEgypt, 12211.

Publication history: Received on 21 August 2020; revised on 26 September 2020; accepted on 28 September 2020

Article DOI: https://doi.org/10.30574/wjarr.2020.7.3.0319

\begin{abstract}
This study was conducted to evaluate the degree of biosecurity level with especial reference to E. coli Spp as an example to explain the expected causes and risk factors that leads to spread them in poultry flocks in Egypt and to evaluate its sensitivity to most common disinfectants used in Egypt. About 300 samples (100 cloacal swabs, 100 liver and intestinal samples,100 litter samples) were collected from 10 broiler farms with different age (at 0 old day, one week,2,4 and 6 weeks of age). The samples were investigated for E. coli Spp and subsequently identified based on biochemical and serological tests. The obtained results showed that 44 isolates were isolated $(27 \pm 1.99 \%) ;(11 \pm 0.42 \%)$ and $(7 \pm 0.72 \%)$ from cloacal swab; liver and litter, respectively. Mean prevalence of $E$. coli spp. was $15 \pm 1.22 \%$. E. coli serotypes were: 078 (31.81\%), O2: H6 (18.18), 01: H7 (15.9), 091: H21(11.36), 0128: H2 (9.09), 026: H11(4.54) 0146: H21, 0124, 044: H18 and 0153: H2. The most common serovars were 0124, 044: H18 and 0153: H2 (2.27\%). In absence of organic matter; there was great statistical significant difference in the sensitivity of $E$. coli to the most common disinfectants $(P<0.05)$ as Verkon- $S^{\circledR}$ achieved 3 log reduction after 5-minute,Formalin and Phenique were achieved 4 $\log$ and $3 \log$ reductions respectively, Aldekol Des- Gda ${ }^{\circledR}$ achieved 4 log reduction, $\mathrm{TH} 4{ }^{\circledR}$,Biosentry ${ }^{\circledR} 904$ and Iodophore achieved $2 \log$ reductions after 5 minutes.
\end{abstract}

Keywords: Broiler farms; Escherichia coli; Serovars; Biosecurity; Disinfection.

\section{Introduction}

The species $E$. coli includes a wide variety of strains, some of which may be responsible for severe infections. However, $E$. coli can become pathogenic through the acquisition of mobile genetic elements such as bacteriophages, pathogenicity islands, and plasmids. Among pathogenic E. coli strains are the Shiga toxin-producing Escherichia coli (STEC) and enteropathogenic $E$. coli (EPEC) strains. The safety concern about foods of poultry origin increased in recent years because of the growing number of human infections with Shiga toxin-producing Escherichia coli. These infections result in illnesses such as mild diarrhoea, bloody diarrhoea, haemorrhagic colitis, and haemolytic uremic syndrome.

E. coli is a member of the family Enterobacteriaceae, which may, constitute a great hazard to poultry industry causing high mortality, loss of weight and reduction of egg production [1].

E. coli infection is one of the serious problems that cause a great threat to the profitability of birds' enterprises all over the word [2]. Although E. coli is a normal inhabitant of the intestinal tract of birds, under the influence of predisposing factors, like inadequate and faulty ventilation, overcrowding, hunger, thirst, extremes of temperatures and low vitality,

\footnotetext{
${ }^{*}$ Corresponding author: Kaoud H A

Department of Veterinary Hygiene and Environmental Pollution, Faculty of Veterinary Medicine, Cairo University, Giza-Egypt, 12211..
}

Copyright $(2020$ Author(s) retain the copyright of this article. This article is published under the terms of the Creative Commons Attribution Liscense 4.0. 
high mortality during rearing, reduced weight gain and condemnation of birds at the time of slaughter. Avian colibacillosis is a complex syndrome characterized by multiple organ lesions with airsacculitis and associated pericarditis, perihepatitis and peritonitis being most typical [3].

The main clinical signs of naturally infected chicks with E. coli are reported as depression, loss of appetite, tendency to huddle respiratory distress, reduction of weight gain, dropped wing, closed eyes, cyanosis and laboured breathing [4].

Reducing bacterial and fungal populations is a major issue in poultry houses [5,6]. The presence of a high population of pathogenic bacteria in broiler grow-out houses can contribute in declining the wellness of the flock and lead to a sensitive production loss.

The principles of disease prevention and control within the poultry industry are based on flock management, biosecurity, preventive vaccination and sanitation [7]. The last step in a cleaning and disinfection program is the actual disinfection process that will further reduce pathogens in the facilities. To maximize the effectiveness of a cleaning and disinfection program, it is crucial to modify such a program based on the suspected pathogens that should be eliminated or reduced. In addition, specific disinfectants may be selected for certain known microbial contaminants following an infectious disease outbreak.

The aim of this study is

- To investigate the contamination of poultry farms with E. coli strains.

- To evaluate the degree of biosecurity level in some broiler farms with especial reference for E. coli.

- To determine the disinfectants sensitivity of $E$. coli to most common disinfectants in Egypt.

\section{Material and methods}

A total of 10 broiler houses were studied from November 2019 to July 2020.The farms were visited at different ages (one day old, week one, week 2, week 4 and week 6 of age). The data collected form the visited farms were description for their construction, bird species, stocking densities, traffic control, pest control, vaccination programmes, disinfection protocol and other managemental criteria. The evaluation process was carried out through filling out a designed questionnaire and taking samples for the isolation of bacterial pathogens.

\subsection{Designed questionnaire}

2.1.1. The biosecurity score was determined by the application the following Questionnaire:

\begin{tabular}{|c|c|}
\hline Biosecurity parameters & Score(code) \\
\hline Self-proofing (bird and house) & (yes $=0.1, \mathrm{no}_{0}=0$ ) \\
\hline Rodent and wild bird proofing & (yes $=0.1, \mathrm{no}_{0}=0$ ) \\
\hline Adequate ventilation area & (yes $=0.1, n_{0}=0$ ) \\
\hline $\begin{array}{l}\text { Adequate distance between farms } \\
\text { and other poultry operations }\end{array}$ & (yes $\left.=0.1, n_{0}=0\right)$ \\
\hline Hygienic disposal of carcass & (yes $\left.=0.1, n_{0}=0\right)$ \\
\hline Self-sufficient & (yes $=0.1, \mathrm{no}_{0}=0$ ) \\
\hline Cleaning and disinfection & (yes $\left.=0.1, n_{0}=0\right)$ \\
\hline Foot dips & (yes $=0.1, \mathrm{no}=0$ ) \\
\hline Traffic control & (yes $=0.1, \mathrm{no}=0$ ) \\
\hline Visitor restriction & (yes $=0.1, \mathrm{no}=0$ ) \\
\hline
\end{tabular}


2.1.2. Correlation coefficient

$$
r=\frac{n\left(\sum x y\right)-\left(\sum x\right)\left(\sum y\right)}{\sqrt{\left[n \sum x^{2}-\left(\sum x\right)^{2}\right]\left[n \sum y^{2}-\left(\sum y\right)^{2}\right]}}
$$

\subsection{Sampling}

- Litter samples $10 \mathrm{gm}$ each) were randomly collected from the commercial broiler farms. 100 samples were collected from the broiler farms (Triple litter samples).

- 100 Cloacal swab samples were collected from the broiler farms (three Cloacal swabs).

- Liver swab samples, 50 samples were collected from the broiler farms (three samples).

- Intestine swab samples, 50 samples were collected from the broiler farms (three samples).

Samples were collected aseptically and then brought to the laboratory in the Department of Veterinary Hygiene and Management, Faculty of Veterinary, Cairo University These samples were subjected to various bacteriological and biochemical examination in the laboratory.

\subsection{Isolation and Identification of $E$. coli}

Nutrient Broth (NB) and Nutrient Agar (NA) were used to grow the organisms from the collected samples before performing biochemical test according to the procedure describe by Cheesebrough [10]. Eosin Methylene Blue (EMB) agar medium was used for observing growth of $E$. coli. Suspected isolates of $E$. coli organisms were identified according to MacFaddin [11].

\subsection{Serological identification of of $E$. coli}

The isolates were serologically identified according to Kok et al. [12] by using rapid diagnostic E. coli antisera sets (DENKA SEIKEN Co., Japan) for diagnosis of the Enteropathogenic types.

\subsection{Preparation of tested E. coli}

\subsubsection{Propagation of the selected bacterial isolate}

The bacterial isolates (E. coli 0153:H2: STEC strain harbouring virulence genes,) were propagated using pour plate method. A loopful was transferred from all bacterial strains that was stored onto nutrient slopes into 10 ml nutrient broth and incubated at $37^{\circ} \mathrm{C}$ for $20-24 \mathrm{~h}$. [8,9].

\subsubsection{Preparation of source of organic matter}

$5 \%$ stock solution of yeast suspension ( $5 \mathrm{~g}$ of dried yeast was added to $100 \mathrm{ml}$ of sterile distilled water); the yeast suspension was dispensed into $5 \mathrm{ml}$ tubes, sterilized by autoclaving for $20 \mathrm{~min}$ at $121^{\circ} \mathrm{C}$.

\subsection{Evaluation of the efficacy of chemical disinfectants}

\subsubsection{Selected disinfectants}

- Potassium proxy Monosulphat (Verkon- $S \circledR 1: 120)$

- Aldehyde / QUACS disinfectant (Aldekol des- Gda®) (0.4\%).

- Quaternary ammonium compound disinfectant (biosentry® $\left.904^{\mathrm{TM}}\right)(0.4 \%)$.

- Quaternary ammonium compounds and glutaraldehyde $\left(\mathrm{TH} 4^{\circledR} 1 \mathrm{ml}\right.$ of $\mathrm{TH} 4{ }^{\circledR}$ solution was added to $100 \mathrm{ml}$ distilled water, $\mathrm{pH}$ 8.7).

- $\quad$ Formalin $(2.5 \%, \mathrm{pH} 7.9)$.

- Iodophore $1 \%$ in water

- $\quad$ Phenique $3 \%$ in water.

\subsubsection{Method of evaluation}

The laboratory evaluation of the efficacy of the chemical disinfectants was carried out using modified use-dilution test [13]. The test was repeated twice; once in the presence of organic matter and the second time in the absence of the organic matter. Bacterial suspension was prepared and propagated. $10 \mathrm{ml}$ of the tested chemical disinfectant were 
poured into a sterile test tubes, $0.1 \mathrm{ml}$ of the bacterial suspension $\left(1-2 \times 10^{8}\right)$ was added and shaken thoroughly to give the chance for micro-organism to come in contact with the disinfectant. At time interval 1, 5, 10 and 30 min from original zero-time $1 \mathrm{ml}$ of disinfectant-bacterial mixture were taken into tube containing $9 \mathrm{ml}$ of in-activator (Tween $803 \%$ ) in nutrient broth, mix thoroughly. One $\mathrm{ml}$ from in-activator tubes was used for the bacterial count using pour plate method [14]. The numbers of survival bacteria on each plate were counted. The calculation was carried out using the following formula: Log (average CFU/ drop vol.) (dilution factor) (Vol. scrapped into/ surface area) [8,9].

\subsubsection{Statistical Analysis}

The data were analyzed by the student $t$ test and One-Way analysis of variance (ANOVA) according to Winer et al.,[15].

\section{Results and discussion}

\subsection{Prevalence of $E$. coli at different ages of broiler farms}

The incidence of $E$. coli in one day old living diseased chicks, 1 week, 2 week, 4 week and 6 weeks of age were $10 \%, 14 \%$ $12 \%, 5.7 \%$ and $10.1 \%$, respectively (Table 1 and Figure 1).

Table 1 Showing_Prevalence of E. coli at different ages.

\begin{tabular}{|l|l|l|l|l|l|}
\hline \multirow{2}{*}{$\begin{array}{l}\text { Age } \\
\text { isolates }\end{array}$} & \multicolumn{4}{l}{ Mean \pm SD \% } \\
\cline { 2 - 6 } & 0 day & 1 week & 2 week & 4week & 6 week \\
\hline E. coli & $10 \pm 0.99 \%$ & $14 \pm 1.22 \%$ & $12 \pm 1.69 \%$ & $5.7 \pm 0.99 \%$ & $10.1 \pm 0.88 \%$ \\
\hline
\end{tabular}

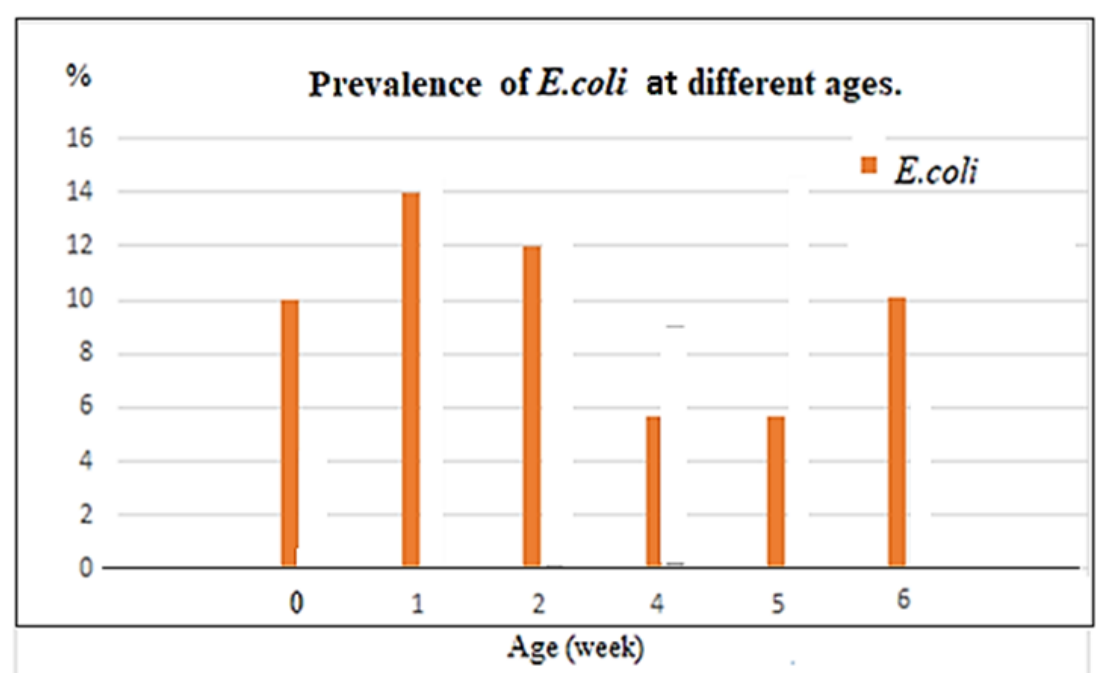

Figure 1 Prevalence of $E$. coli at different ages

\subsection{Prevalence of $E$. coli in broiler farms}

The obtained results showed that $44 \%$ E. coli were isolated from 10 broiler poultry houses $(27 \%) ;(11 \%)$ and $(7 \%)$ from cloacal swab; Liver and Litter, respectively, as shown in Table 2 and Figure 2.

\subsubsection{Prevalence of E. coli in different breeds}

Mean prevalence of E. coli spp. was $15 \%$ in Cobb, Ross or Sasso breeds, Tapan et al., [16] detected colibacillosis from different farms. the highest isolation rate of E. coli from yolk sac (52.6\%) and heart blood (38.4) in one day old -4week, and the highest percentage of $E$. coli isolation was from pericardial fluid (35.8\%) followed byheart blood (33.4\%) in older age (4-7 week). AbdElatif [17] examined 150 samples taken from five broiler chickens revealed the isolation of $E$. coli with percentage of $78.7 \%$, where the isolation from apparently healthy chickens with percentage of $72.0 \%$ and clinically diseased chickens with percentage of 85.3\%, respectively. From the isolated E. coli, 208 strains recovered from different organs of chickens relieved that158 strains can be serotyped serologically and belonged to different serogroups. 
Table 2 Showing mean incidence of $E$. coli in different samples of broilers poultry farms.

\begin{tabular}{|l|l|l|}
\hline Types of samples & No. of samples & E. coli spp. \\
\hline Cloacal swab & 100 & $27 \pm 1.99 \%$ \\
\hline Liver & 50 & $4 \pm 0.12 \%$ \\
\hline Intestine & 50 & $7 \pm 0.30 \%$ \\
\hline Litter & 100 & $7 \pm 0.72 \%$ \\
\hline Total \% & 300 & $15 \pm 1.22 \%$ \\
\hline
\end{tabular}

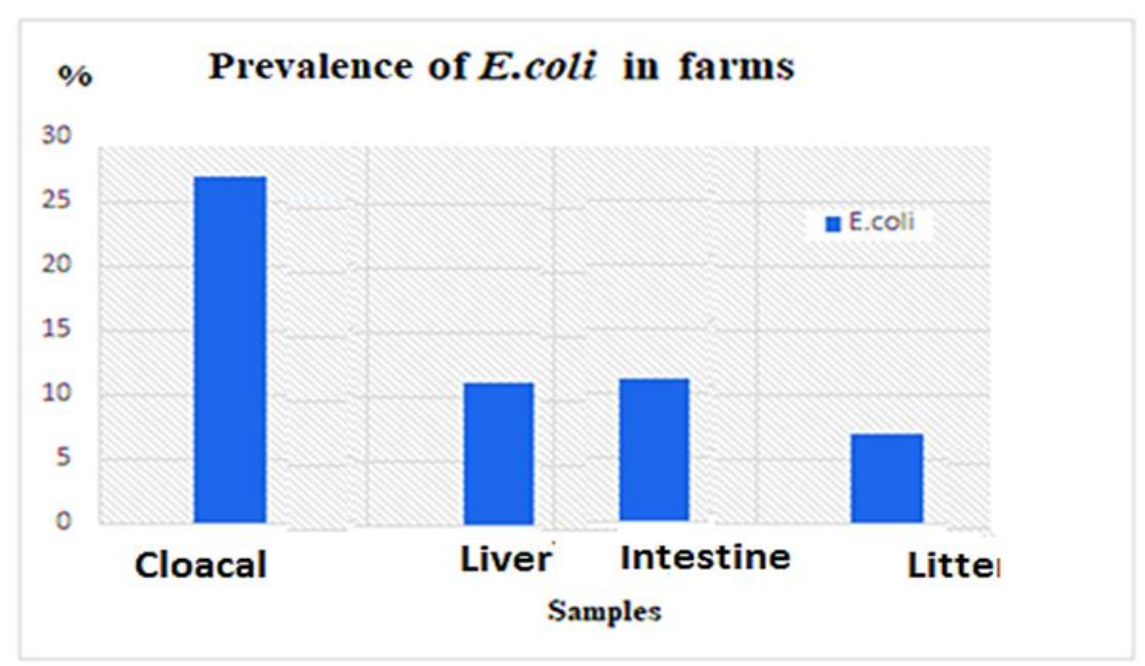

Figure 2 Mean Prevalence $\pm S D \%$ of $E$. coli in different samples of broilers poultryfarms.

\subsection{Prevalence of $E$. coli serotypes isolated from the studied farms}

Table 3 Showing Prevalence of E. coli serotypes isolated from the studied farms

\begin{tabular}{|l|c|c|}
\hline Serotypes & $\begin{array}{c}\text { Number of } \\
\text { isolates }\end{array}$ & Percentage \\
\hline O78 & 14 & 31.81 \\
O2: H6 & 8 & 18.18 \\
O1: H7 & 7 & 15.9 \\
O91: H21 & 5 & 11.36 \\
O128: H2 & 4 & 9.09 \\
O26: H11 & 2 & 4.54 \\
O146: H21 & 1 & 2.27 \\
O124 & 1 & 2.27 \\
O44: H18 & 1 & 2.27 \\
O153: H2 & 1 & 2.27 \\
\hline Total & 44 & - \\
\hline
\end{tabular}

O78 (31.81\%), O2: H6 (18.18), O1: H7 (15.9), 091: H21(11.36), 0128: H2 (9.09), O26: H11(4.54) 0146: H21. The percentage of isolated E. coli serotypes 0124, 044: H18 and 0153: H2 was 2.27\%. 


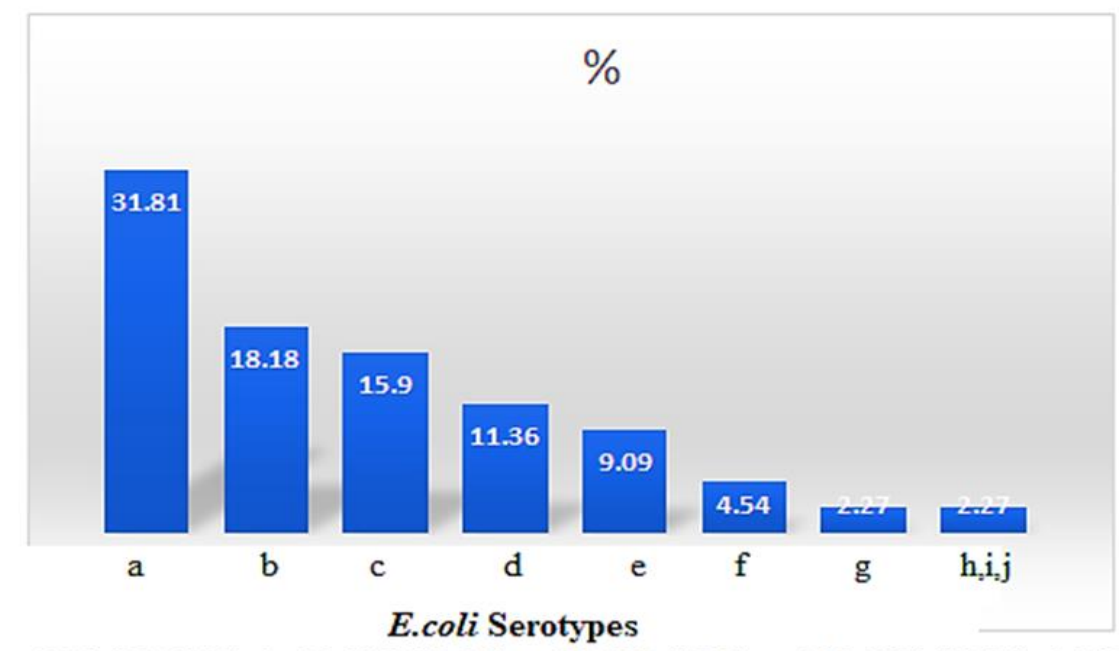

a:O78 (31.81\%), b O2: $\mathrm{H} 6$ (18.18), c: O1: $\mathrm{H} 7$ (15.9), c:O91: $\mathrm{H} 21(11.36), \mathrm{dOO} 128$ : $\mathrm{H} 2$

(9.09) e: O26: $\mathrm{H} 11(4.54), \mathrm{f}: \mathrm{O} 146: \mathrm{H} 21, \mathrm{~g}: \mathrm{O} 124, \mathrm{~h}: \mathrm{O} 44 \mathrm{i}:=\mathrm{H} 18, \mathrm{j}: \mathrm{O} 153: \mathrm{H} 2$

Figure 3 Prevalence of E. coli serotypes isolated from the studied farms

The detected E. coli serogroups in our study were; 078 (31.81\%), O2: H6 (18.18), 01: H7 (15.9), 091: H21(11.36),0128 : H2 (9.09),O26: H11(4.54) 0146: H21.The percentage of isolated E. coli serotypes 0124, O44: H18 and 0153 : H2 was $2.27 \%$,as shown in Table 3 and Figure 3.

The most commonly detected E. coli serogroups serotyped by Tapan et al., [16] were 044 (11.3\%), 0158 (11.3\%), 0125(7.5\%), 0103 (9.4\%), 063 (7.5\%), 091(8.8\%), while 50 strains were un- typed.

These results go hand to hand with the previous studies of $[18,19,20,21]$ who reported that serogroups $044,0158,0114$ and 091 were traditionally associated with colibacillosis in poultry.

\subsection{The biosecurity scores in relation to mortality $\%$ and prevalence of isolation}

Table 4 Showing Biosecurity score, Prevalence of E. coli in the studied farms

\begin{tabular}{|l|l|l|}
\hline \multirow{2}{*}{ Biosecurity } & \multirow{2}{*}{ Mort. \% } & Prevalence of isolate \\
\cline { 3 - 3 } & & E. coli \\
\hline 0.6 & 12 & $43.7 \%$ \\
\hline 0.4 & 15 & $81.3 \%$ \\
\hline 0.8 & 8 & $68.7 \%$ \\
\hline 0.5 & 15 & $50 \%$ \\
\hline 0.4 & 20 & $75 \%$ \\
\hline 0.8 & 6 & $43.7 \%$ \\
\hline 0.4 & 20 & $25 \%$ \\
\hline 0.5 & 15 & $25 \%$ \\
\hline 0.7 & 12 & $56.3 \%$ \\
\hline 0.7 & 12 & $68.7 \%$ \\
\hline
\end{tabular}




\subsubsection{The Correlation coefficient between biosecurity level and Mortality rate}

Form Table 4 and fig,4a we found that there was strong association concerning level of applied biosecurity in broiler farms and mortality rate (significant negative $P<0.05)(\mathbf{R}=0.8545)$, its means that the mortality rate ' will be reduced significantly $(P<0.05)$ if the satisfactory biosecurity applied to such farms.

\subsubsection{The Correlation coefficient between biosecurity level and E. coli spread}

Form Table 4 and fig, $4 \mathrm{~b}$ we found that there was a very strong association concerning level of applied biosecurity in broiler farms and $E$. coli spread (significant negative $P<0.05$ ) The value of $\mathrm{R}$ is NaN. This is a strong negative correlation, which means that high $\mathrm{X}$ variable scores go with low $\mathrm{Y}$ variable scores (and vice versa).

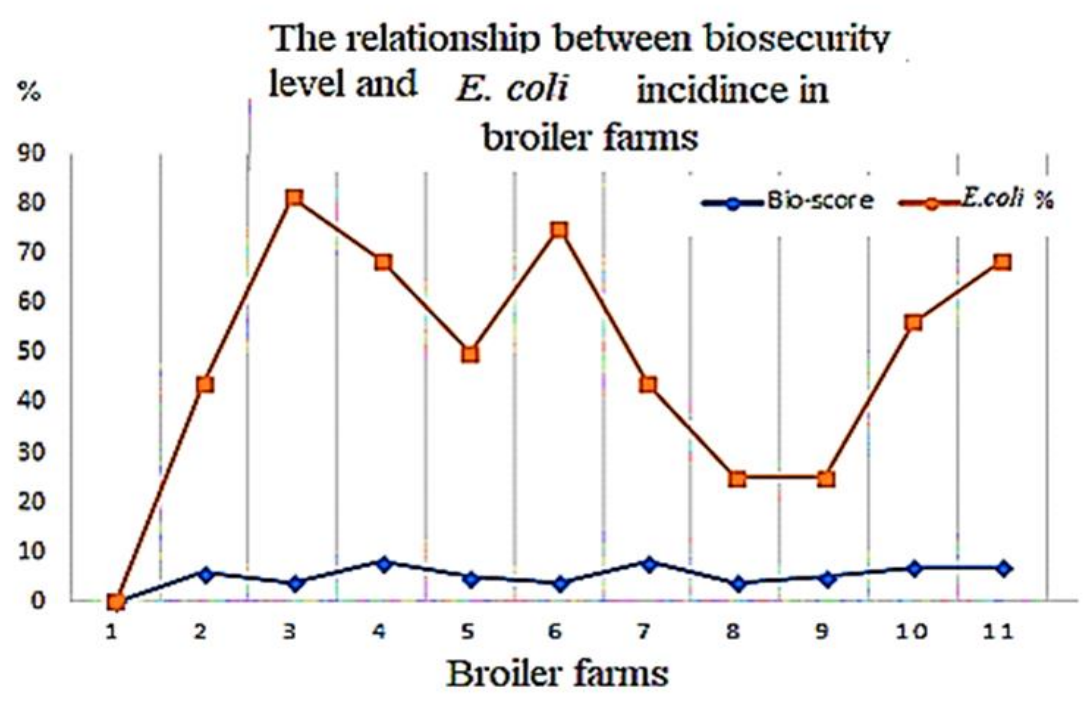

Figure 4a Biosecurity score, Prevalence of $E$. coli in the studied farms

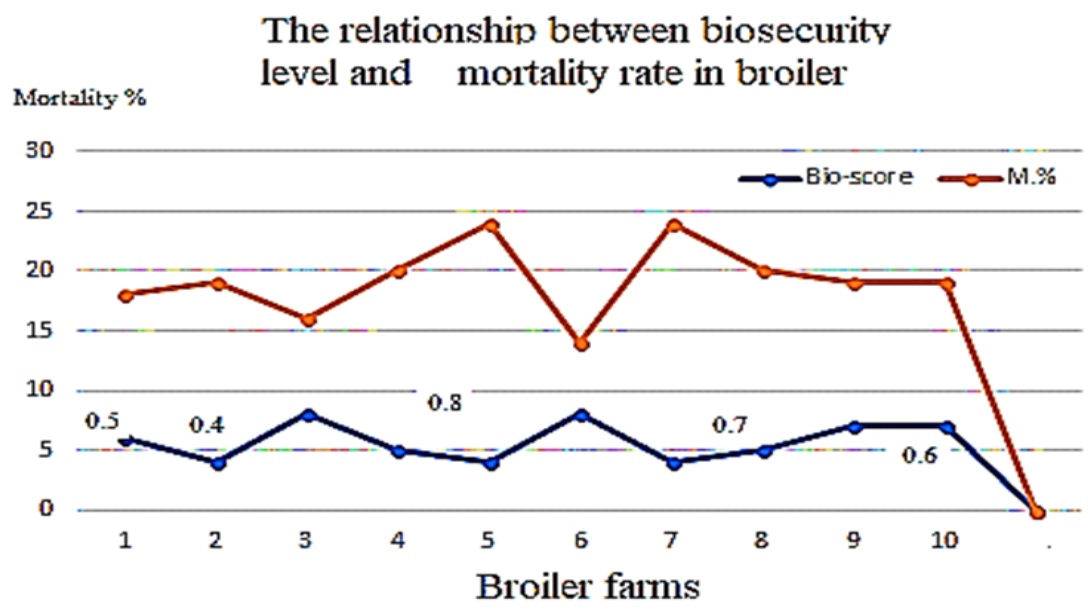

Figure $4 \mathbf{b}$ Biosecurity score and Mortality rate due to spread of $E$. coli in the studied farms

\subsection{Evaluation of the efficacy of chemical disinfectants}

\subsubsection{Evaluation of the efficacy of chemical disinfectants against E. coli in the absence of organic matter}

In the absence of organic matter,Verkon- $S^{\circledR}$ Aldekol Des- Gda ${ }^{\circledR}, T H 4{ }^{\circledR}$, Biosentry ${ }^{\circledR} 904^{\mathrm{TM}}$ and Formalin ${ }^{\circledR}$ achieved $100 \%$ efficacy against Escherichia coli after $10 \mathrm{~min}(\mathrm{p}<0.05)$ while Iodophore ${ }^{\mathrm{m}}$ and Phenique were achieved $3 \log$ reduction against Escherichia coli after $30 \mathrm{~min}(\mathrm{p}<0.05)$,as shown in Table 5 and Figure 5. 
Table 5 The Mean viable colony count $(\mathrm{cfu} / \mathrm{ml})$ of $E$. coli after contact time with the tested disinfectants in the absence of organic matter.

\begin{tabular}{|c|c|c|c|c|c|}
\hline contact time & $\begin{array}{l}\text { Initial } \\
\text { count }\end{array}$ & $1 \mathrm{~min}$ & $5 \mathrm{~min}$ & $10 \mathrm{~min}$ & $30 \mathrm{~min}$ \\
\hline Verkon- $\mathrm{S}^{\otimes}$ & $1.5 \times 10^{8}$ & $\log 6^{a}$ & $\log 5^{a}$ & $\log 4^{a}$ & $\log 4^{a}$ \\
\hline Aldekol Des- Gda & $3.6 \times 10^{8}$ & $\log 6^{a}$ & $\log 4^{\mathrm{a}}$ & $\log 3^{a}$ & $\log 3^{a}$ \\
\hline $\mathrm{TH} 4^{\Theta}$ & $3.6 \times 10^{8}$ & $\log 7 b$ & $\log 6^{a}$ & $\overline{\log 4^{a}}$ & $\overline{\log 4^{a}}$ \\
\hline Biosentry $904^{\mathrm{Ts}}$ & $3.6 \times 10^{8}$ & $\log 7 b$ & $\log 6^{a}$ & $\log 4^{\mathrm{a}}$ & $\log 4^{a}$ \\
\hline Iodophore $^{\text {TII }}$ & $1.5 \times 10^{8}$ & $\overline{l o g} 5 a$ & $\overline{l o g} 5 a$ & $\log 5 \mathrm{a}$ & $\overline{\log 5 a}$ \\
\hline Formalin & $1.2 \times 10^{8}$ & $\log 5 a$ & $\log 4 a$ & $\overline{l o g} 4 a$ & $\overline{\log 4 a}$ \\
\hline Phenique & $1.5 \times 10^{8}$ & $\log 5 a$ & $\log 5 a$ & $\log 5 a$ & $\log 5 a$ \\
\hline
\end{tabular}

The Mean $\log$ reduction (log 10 ) of $E$.coli after contact time with the tested disinfectantsin the absence of organic matter

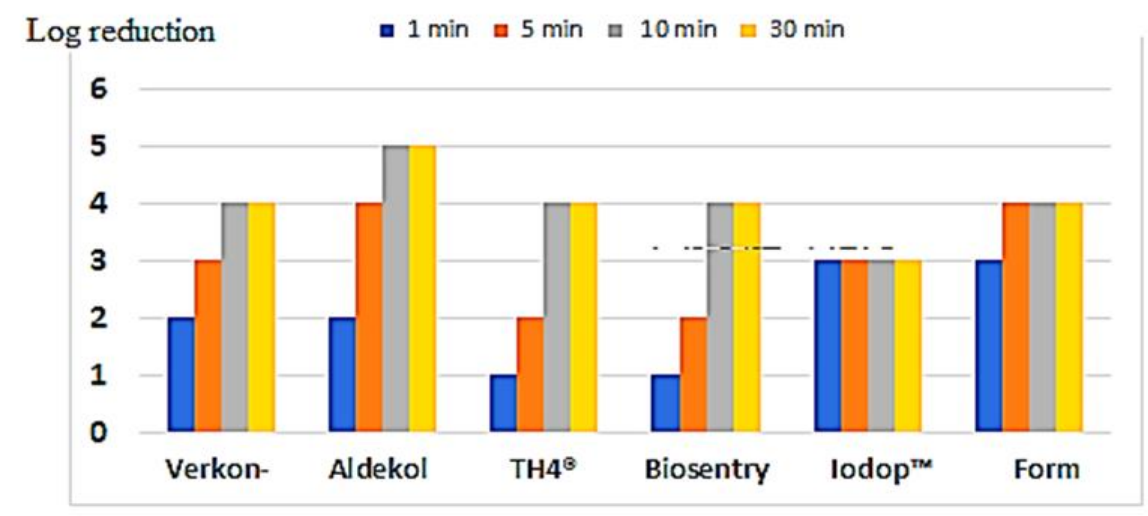

\section{Disinfectants}

Figure 5 The Mean viable colony count (cfu/ml) of $E$. coli after contact time with the tested disinfectants in the absence of organic matter.

\subsubsection{Evaluation of the efficacy of chemical disinfectants in the presence of organic matter}

In the presence of organic matter, Verkon- $\mathrm{S}^{\circledR}$ achieved 3 log reductions after 5 min, but Aldekol Des- Gda ${ }^{\circledR}$ and Iodophore were achieved 3 log reductions after 30 min against Escherichia coli $(\mathrm{P}<0.05)$ without any log reduction after words (Table 6 and Figure 6).

On the other hand, Formalin achieved 4 log reductions after 5 min against Escherichia coli $(\mathrm{P}<0.05)$ without any log reduction after words. $\mathrm{TH}^{\circledR}{ }^{\circledR}$ was achieved 2 log reductions after 5 min against Escherichia coli $(\mathrm{P}<0.05)$ while Biosentry ${ }^{\circledR} 904^{\mathrm{TM}}$ and Phenique were $2 \log$ reductions after 10 min without any log reduction after words. 
Table 6 The Mean viable colony count (cfu/ml) of E. coli after contact time with the tested disinfectants in the presence of organic matter.

\begin{tabular}{|c|c|c|c|c|c|}
\hline Disinfectant $/$ contact time & Initial count & $1 \mathrm{~min}$ & $5 \mathrm{~min}$ & $10 \mathrm{~min}$ & $30 \mathrm{~min}$ \\
\hline Verkon- $S^{\otimes}$ & $1.5 \times 10^{8}$ & $\log 6^{a}$ & $\log 5^{a}$ & $\log 5^{a}$ & $\log 5^{a}$ \\
\hline Aldekol Des- Gda & $3.6 \times 10^{8}$ & $\log 6^{a}$ & $\log 6^{a}$ & $\log 6$ & $\log 5^{a}$ \\
\hline TH $^{\otimes}{ }^{\otimes}$ & $3.6 \times 10^{8}$ & $\log 7^{b}$ & $\log 6^{a}$ & $\log 6^{a}$ & $\log 6^{a}$ \\
\hline Biosentry $904^{\mathrm{Tx}}$ & $3.6 \times 10^{8}$ & $\log 7^{b}$ & $\log 7^{b}$ & $\log 6^{a}$ & $\log 6^{a}$ \\
\hline Iodophore $^{\mathrm{Tax}}$ & $1.5 \times 10^{8}$ & $\log 7^{b}$ & $\log 7^{b}$ & $\log 7^{b}$ & $\log 5^{a}$ \\
\hline Formalin & $1.2 \times 10^{8}$ & $\log ^{5 a}$ & $\log 4 a$ & $\log ^{4 a}$ & $\log ^{4 a}$ \\
\hline Phenique & $1.5 \times 10^{8}$ & $\log 6^{a}$ & $\log 6^{a}$ & $\log 6^{a}$ & $\log 6^{a}$ \\
\hline
\end{tabular}

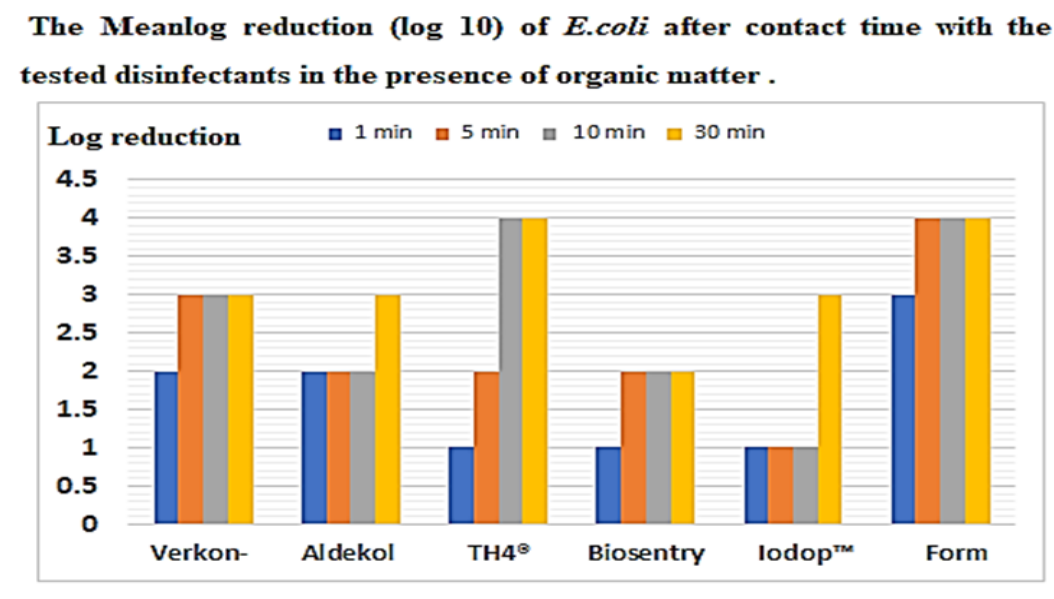

Disinfectants

Figure 6 The Mean log reduction (Log 10) of E. coli after contact time with the tested disinfectants in the presence of organic matter.

In case of Formalin, it achieved 3 log reduction after one min while Phenique achieved one log reduction after one min without any log reduction after words Mohamed [22] concluded that all used disinfectants were affected by presence of organic matter except formalin solution. He found that the best reduction in total bacterial count were obtained with $10 \%$ formalin solution followed by Creolin 3\% while lower efficiency was recorded when iodophor preparation was applied. Formaldehyde and phenolic compound were effective in presence of organic matter. The poultry houses and equipment should be fogged with formaldehyde solution which might be repeated after placing the litter. Ka-Oud [23] found that $1 \%$ formalin failed to produce its germicidal action on pathogenic E. coli of an artificially infected litter after 30 minutes, while in a concentration of $5 \%$ it destroyed E. coli within the same exposure time. E. coli strains were susceptible to in-use concentrations of formaldehyde, benzalkonium chloride and a formulation of peracetic acid and hydrogen peroxide $\mathrm{M}(24)$.

\section{Conclusion}

From the findings we can concluded that the most prevalent E. coli serovars in broilers were: 078 , $02: \mathrm{H6}, 01: \mathrm{H} 7$, 091: H21, 0128: H2 , 026: H11, 0146: H21, 0124, 044: H18 and 0153: H2 . There was a strong association concerning level of applied biosecurity and mortality rate, its means that the mortality rate will be reduced significantly if a satisfactory biosecurity applied to such farms. Also, the variables, such as application rate, disinfectant type, time of exposure, and the presence or absence of organic matter, are important considerations when including a chemical 
disinfectant application into a sanitation program. The potassium peroxymonosulfate, nascent oxygen, formalin and phenol products provided the best E. coli reductions in the laboratory trials.

\section{Compliance with ethical standards}

\section{Acknowledgments}

Acknowledgments to the regional center for food and feed, agriculture research center and laboratory, Egypt.

\section{Disclosure of conflict of interest}

The authors declare that there is no conflict of interest regarding the publication of this article.

\section{References}

[1] Bandyopadhay PK, Dhawedkar RG. E. coli salping operitonitis in poultry. Indian Vet. J. 1984; 61: 348-349.

[2] Saha AK, Sufian MA, Hossain MI, Hossain MM. Salmonellosis in layer chickens: pathological features and isolation of bacteria from ovaries and inner content of laid eggs. J. Bangladesh Agril. Univ. 2012; 10(1): 61-67.

[3] Ewers C, Janssen T, Kiessling S, Philipp HC, Wieler LH. Molecular epidemiology of avian pathogenic Escherichia coli (APEC) isolated from colisepticemiae in poultry. 9. Vet. Microbiol. 2004; 104 (1-2): 91-101.

[4] Barnes HJ, Gross WB. Colibacillosis. In: Calnek BW, Beard CW,McDougald LM,Saifin YM. editors. Dis. of poult. Ames:Iowa State University Press. 1994; 131-141.

[5] Barnes HJ, Nolan lk, vaillancourt JA. Colibacillosis in Saif YM, Fadly AM. Disease of poultry. Blackwell Publishing, Ames, IA PP. 2008; 691-732.

[6] Payne B, Kroger EC, Watkins SE. Evaluation of Disinfectant Efficacy When Applied to the Floor of Poultry GrowOut Facilities. Poultry Science Association, Inc. 2005.

[7] Zander DV, Bermudez AJ, Mallinson ET. Principles of disease prevention: diagnosis and control. In: Calnek BW ed. Diseases of Poultry. 10th ed. 1997; 3 /45.

[8] Zelver N, Hamilton M, Pitts B, Goeres D, Walker D, Sturman P, Heersink J. Measuring antimicrobial effects on biofilm bacteria. In: RJ Doyle et al. ed (s). Biofilm: methods in enzymology, Academic Press, San Diego, CA 1999; 608-628.

[9] Herigstad B, Hamilton M, Heersink J. How to optimize the drop plate method for enumerating bacteria. Journal of Microbiological Methods. 2001; 44: 121-129.

[10] Cheesbrough M. Culture Media. In: Cheesbrough, M., ed. Medical Laboratory Manual for Tropical Countries. Tropical Health Technology and Butterworth-Heineman, Cambridge. 1984; 60-69.

[11] MacFaddin JF. Biochemical Tests for Identification of Medical Bacteria, 3rd ed. Williams and Wilkins, Philadelphia, P. A. 2000.

[12] Kok T, Worswich D, Gowans E. Some serological techniques for microbial and viral infections. In: Practical Medical Microbiology, Collee J, Fraser A, Marmion B, Simmons A., eds. 14th ed., Edinburgh, Churchill Livingstone, UK. 1996.

[13] Robinson RA, Bodily HL, Robinson DF, Christensen RP. A suspension method to determine reuse life of chemical disinfectants during clinical use. Appl. Environ. Microbiol. 1988; 54:158-164.

[14] Cruickshank R, Duguid JP, Marimion BP, Swain RH. Medical microbiology. E.L.B.S. 12th ed. vol. 11, reprinted Churchill Livingstone and Robert Stevenso. Edinburgh, EHI, 3AF. 1980.

[15] Winer BJ, Brown DR, Michels KM. Statistical principles in experimental design. 3rd ed. New York: McGraw-Hill. 1991.

[16] Tapan KS, Lakshman S, Laxmi N, Sarangi S, Kumar P, Hemant KP. Prevalence, Isolation, Characterization and Antibiogram Study of Pathogenic Escherichia coli from Different Poultry Farms of Odisha. Journal of Advanced Veterinary Research. 2012; 2: 169-17. 
[17] AbdElatif MM. E. coli associated with swollen head syndrome in broiler chickens. Assiut Vet. Med. J. 2004; 50(101): 188-189.

[18] Suwanichkul A, Panigrahy H. Diversity of piles subunits of E. coli isolated from avian species. Avian Dis. 1988; 32(4): 822-825

[19] Gross WB. Colibacillosis diseases of poultry, 9thEd: pp. 38-144 Editors. 1991.

[20] Bosch JF, Hendricks JH, Gladigan I, Willimes HM, Storm PK, Graaf FK, Van-den-Bosch Graaf FK. Identification of fimbriae on chicken E. colistrains. Infect. Immune. 1993; 61(3): 800-806.

[21] Ibrahim RA, Cryer TL, Lafi SQ Abu Basha E, Good L, Tarazi YH. Identification of Escherichia coli from broiler chickens in Jordan, their antimicrobial resistance, gene characterization and the associated risk factors. BMC Veterinary Research. 2019; 15: 159.

[22] Mohamed MA. Evaluation of Disinfection Process in Modern Poultry Farms. [M.V.Sc. Thesis] Fac. of Vet. Med. Cairo University. 1990.

[23] Ka-oud HA. Hygienic Studies on E. coli in Poultry Farms in Egypt. J. Egypt. Vet Med. Ass 1986; 46(3): 243-249.

[24] Maertens H, De Reu K, Meyer E, Coillie E, Dewulf J. Limited association between disinfectant use and either antibiotic or disinfectant susceptibility of Escherichia coli in both poultry and pig husbandry BMC Veterinary Research. 2019; 15: 310. 